\title{
Effects of edaphic conditions and flowering period on the rhizosphere mycoflora of Adhatoda vasica Nees
}

\author{
INDER JEET JOSHI \\ School of Studies in Botany, Jiwaji University, \\ Gwalior-474011, India \\ (Received: May 5, 1983. Accepted: August 4, 1983)
}

\begin{abstract}
Non-rhizosphere, rhizosphere and rhizoplane mycoflora of Adhatoda vasica Nees growing in two different soil types was studied during winter and rainy seasons. The effect of edaphic conditions and flowering period on the non-rhizosphere, rhizosphere and rhizoplane mycoflora was studied. Qualitative as well as quantitative variations in the non-rhizosphere, rhizosphere and rhizoplane mycoflora were studied in relation to soil types and seasons. The dominance of different fungal species and specific fungal groups in the non-rhizosphere, rhizosphere and rhizoplane of $A$. vasica was described in relation to soil types and seasons.
\end{abstract}

Key words: Adhatoda vasica, mycoflora, rhizosphere, edaphic conditions, flowering period

\section{INTRODUCTION}

The rhizosphere mycoflora is known to affect the growth of soil borne plant pathogens, root respiration (Katznelson and $\mathrm{Rouatt}$ 1957), mineral nutrient uptake ( $\mathrm{S} \mathrm{ubba} \mathrm{R}$ a o et al. 1961), as well as plant growth (Pidoplichko et al. 1965). Most of the workers have noted maximum rhizosphere community during the flowering period when the plant shows luxurient growth (Srivastava 1973, Gangawane and Deshpande 1977, Shukla and Dwivedi 1981) and this has been attributed to the maximum root exudation during the flowering period.

Although considerable research has been done on the rhizosphere mycoflora of various plants with regard to their flowering periods, fewer studies have been performed on the rhizosphere mycoflora of trees and shrubs (Mishra and Kanaujia 1973, Peno and Veselinovic 1973, Karimbaeva and Sizova 1976) due to difficulties in handling their root systems. Consequently, very little is known about 
the rhizosphere mycoflora of woody plants with regard to their flowering periods. In an investigation on the rhizosphere mycoflora of certain trees ( $\mathrm{J}$ os h i 1982), maximum rhizosphere mycocommunity was noted during their corresponding flowering periods. In view of these results, in the present study an attempt is made to investigate the rhizosphere mycoflora of Adhatoda vasica Nees which is an important medicinal shrub and is one of the dominant plants occurring in Chambal ravines of Bhind, India. The non-rhizosphere, rhizosphere nad rhizoplane mycoflora of A. vasica growing in two different soil types is studied during winter and rainy seasons to elaborate the effect of edaphic conditions and flowering period on the non-rhizosphere, rhizosphere and rhizoplane mycoflora of A. vasica.

\section{MATERIALS AND METHODS}

This investigation was carried out on Adhatoda vasica Nees growing in two different soil types of Chambal ravines of Bhind (M. P.), India. Soil type I was characterized by sandy loam soils and the other dominant plants growing in this soil type include Dichrostachys cinerea L., Salvadora oleoides DC., and Grewia flavescens Juss. Soil type II was clayey lam in texture and the other dominant plants of this soil type include Prosopis juliflora (SW) DC and Dalbergia sissoo Roxb both of which are being used for afforestation to reclaim these ravines. The non-rhizosphere, rhizosphere and rhizoplane mycoflora of $A$. vasica growing in the two soil types was studied during winter and rainy seasons.

The non-rhizosphere soil samples were collected upto a depth of $10 \mathrm{~cm}$ from the place $15 \mathrm{~cm}$ away from the roots and the mycoflora was isolated on Martin's rose bengal streptomycin medium (M a r tin 1950) using soil plate method (W a r c u 1950). After the roots were carefully removed from the soil, the rhizosphere mycoflora was isolated on modified Martin's medium (Papavizas and Davey 1959) using dilution plate method ( $\mathrm{T}$ i m on in 1940). For rhizoplane mycoflora, serial root washing technique ( $\mathrm{H}$ a r le y and $\mathrm{W}$ a id 1955) was used and the fungi was isolated on Czapek's Dox + Yeast extract medium (S tover and W a i te 1953).

Fungal community was expressed as fungi per g dry soil in case of non-rhizosphere soil and rhizosphere soil; and fungi per g fresh root in case of rhizoplane. Besides this, frequency and abundance of individual fungal species was calculated by the method suggested by $\mathrm{Saksena}$ (1955) and the species with higher frequency and abundance were considered as dominants. Similarity Quotients (Sorensen 1948) were evaluated to compare the non-rhizosphere, rhizosphere and rhizoplane mycoflora. 
The non-rhizosphere soil was analysed for certain edaphic factors. Mechanical composition of the soil was evaluated by Bouycous Hydrometer method ( $\mathrm{Piper}$ 1944). Soil moisture was estimated by oven drying soil samples at $105 \pm 1^{\circ} \mathrm{C}$ for $24 \mathrm{hrs}$. Water holding capacity and organic carbon were determined by methods suggested by P i p e r (1944). Total nitrogen was estimated by semimicro Khjeldahl method; exchangeable calcium nad potassium by flame photometer method; and available phosphorus by Olsen's colorimetric method (J a c k s on 1958).

The data were statistically analysed for Standard Deviations and Analysis of Variance.

\section{RESULTS AND DISCUSSION}

The results of present investigation are given in Tables 1-7. Table 1 reveals the mechanical composition and soil texture of the two soil types, whereas Table 2 deals with the edaphic factors of their non-rhizosphere soil. Table 3 shows the fungal community in the non-rhizosphere, rhizosphere and rhizoplane of A. vasica, whereas Table 4 deals with the distribution of fungal species. Table 5 deals with the similarly quotients, Table 6 deals with the frequency and abundance of some dominant fungi, whereas Table 7 shows percentage occurrence of specific fungal groups in the non-rhizosphere, rhizosphere and rhizoplane of A. vasica.

T a b le 1

Mechanical composition and soil texture of the two soil types $( \pm \mathrm{SD})$

\begin{tabular}{|l|c|c|}
\hline \multicolumn{1}{|c|}{$\begin{array}{c}\text { Mechanical } \\
\text { composition, } \\
\%\end{array}$} & Soil type I & Soil type II \\
\hline Sand & $61.78 \pm 2.01$ & $48.34 \pm 5.72$ \\
Silt & $17.02 \pm 1.80$ & $22.82 \pm 2.26$ \\
Clay & $15.62 \pm 2.04$ & $18.73 \pm 3.66$ \\
$\mathrm{CaCO}_{3}$ & $8.73 \pm 0.75$ & $10.11 \pm 0.38$ \\
\hline Soil texture & sandy loam & clayey loam \\
\hline
\end{tabular}

The two soil types selected for study did not differ significantly with regard to their non-rhizosphere soil fungal community during the rainy season (Table 3) due to statistically insignificant variations in the soil moisture, water holding capacity, carbon, nitrogen, calcium, potassium and phosphorus contents of two soil types (Table 2). However, during the winter season, although soil moisture, water holding capacity, nitrogen, calcium, potassium and phosphorus contents of the two soil types 
Table 2

Edaphic factors of non-rhizosphere soil of both soil types in relation to seasons

\begin{tabular}{|c|c|c|c|c|c|}
\hline 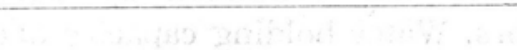 & Winte & season & Rain & season & \\
\hline Factors & $\begin{array}{l}\text { soil } \\
\text { type I }\end{array}$ & $\begin{array}{c}\text { soil } \\
\text { type II }\end{array}$ & $\begin{array}{c}\text { soil } \\
\text { type I }\end{array}$ & $\begin{array}{c}\text { soil } \\
\text { type II }\end{array}$ & L.S.D. \\
\hline Moisture, $\%$ & 4.41 & 3.07 & 10.47 & 11.90 & $4.10^{*}$ \\
\hline Water holding capacity, $\%$ & 37.67 & 39.65 & 49.04 & 47.71 & $4.00^{*}$ \\
\hline Organic carbon, $\%$ & 0.271 & 0.506 & 0.386 & 0.464 & $0.089 * *$ \\
\hline Total nitrogen, $\%$ & 0.042 & 0.070 & 0.056 & 0.060 & 0.043 \\
\hline Exchangeable calcium, $\mathrm{mg} \cdot 100 \mathrm{~g}^{-1}$ & 134.03 & 135.42 & 122.89 & 146.53 & 42.09 \\
\hline Exchangeable potassium, $\mathrm{mg} \cdot 100 \mathrm{~g}^{-1}$ & 39.17 & 46.67 & 35.67 & 42.50 & 16.69 \\
\hline Available phosphorus, ppm & 10.33 & 12.67 & 12.33 & 15.00 & 7.19 \\
\hline
\end{tabular}

* Variations during seasons significant at 5\% level.

$* *$ Variations between soil types significant at $5 \%$ level.

Table 3

Fungal community in the non-rhizosphere, rhizosphere and rhizoplane of Adhatoda vasica in relation to soil types and seasons

\begin{tabular}{|l|c|c|c|c|}
\hline Season & Soil type & $\begin{array}{c}\text { Non-rhizo- } \\
\text { sphere soil } \\
\text { fungal } \\
\text { community } \\
\cdot \mathrm{g}^{-1} \text { soil }\end{array}$ & $\begin{array}{c}\text { Rhizosphere } \\
\text { soil fungal } \\
\text { community }\end{array}$ & $\begin{array}{c}\text { Rhizoplane } \\
\text { fungal } \\
\text { community }\end{array}$ \\
\hline Winter & soil type I & $45.87 \times 10^{-1}$ & $0.15 \times 10^{5}$ & $18.53 \times 10^{2}$ \\
Rainy & soil type II & $66.59 \times 10^{3}$ & $4.47 \times 10^{5}$ & $1.12 \times 10^{2}$ \\
& soil type I & $22.22 \times 10^{3}$ & $4.55 \times 10^{5}$ & $12.67 \times 10^{2}$ \\
soil type II & $40.98 \times 10^{3}$ & $94.05 \times 10^{5}$ & $1.72 \times 10^{2}$ \\
\hline L.S.D. & & $20.05^{*}$ & $15.06^{*}$ & $2.49^{*}$ \\
\hline
\end{tabular}

* Variations significant at $5 \%$ level.

did not differ significantly, the carbon contents of the clayey loam soils of soil type II were significantly higher than that of sandy loam soils of soil type I and hence the non-rhizosphere soil fungal community of the soil type II was also significantly higher than that of soil type I. Earlier studies have also revealed a positive correlation between the fungal community and carbon contents of the soil (K i e m et al. 1975, $\mathrm{Kanazawa} 1979$, Joshi and $\mathrm{Chauhan} 1982 \mathrm{a})$. Seasonally, the non-rhizosphere soil fungal community of both soil types decreased significantly during the rainy season due to significantly higher moisture contents and water holding capacity. In earlier investigations also the soil fungal community has been negatively correlated with the excessively higher moisture contents and water holding capacity ( $\mathrm{J}$ os hi and 
Distribution of fungl in the non-rhizosphere so11 (NRs), rhizosphere so11 (Rs) and rhizoplane (Rp) of Adhatoda vasica in relation to soll types and seasons

\begin{tabular}{|c|c|c|c|c|c|c|c|c|c|c|c|c|}
\hline \multirow[b]{2}{*}{ Fungal species } & \multicolumn{6}{|c|}{ Winter season } & \multicolumn{6}{|c|}{ Rainy season } \\
\hline & $\frac{5011}{N 85}$ & & $\frac{e}{20}$ & $\frac{501}{129}$ & & $\frac{e I}{80}$ & $\frac{5011}{250}$ & & $\frac{e I}{80}$ & 5012 & & \\
\hline & 1 & 2 & 3 & 4 & 5 & 6 & 7 & 8 & 9 & 10 & 91 & 12 \\
\hline \multicolumn{13}{|l|}{ ZYGorrootima } \\
\hline $\begin{array}{l}\text { Cunninghamella echinulata (Thaxt.) Thaxt, ex } \\
\text { Blakesiee }\end{array}$ & + & - & - & + & - & - & - & - & - & - & - & - \\
\hline Mucor hiemalis Wehmer & + & + & + & - & - & - & - & + & + & - & - & - \\
\hline K. racenosus Fresenius & - & - & - & + & - & - & - & - & - & - & - & - \\
\hline Phizopus oryzae went \& Prinsen Geerligs & + & + & - & + & - & + & + & - & - & + & - & + \\
\hline
\end{tabular}

\section{AsCONYCOTINA}

Candida sp.

Chaetomiun globosum Kunze ex Fr.

c. jodhpurense Lodha

Chaetorium sp.

Cymnoascus zuffianus Morini

Khuskia oryzae Hudson

Narasimhella hyalinospora (Kuehn, Orw \& Chosh) Von Arx

Neocosmospora vasinfecta E.F. Swith Petriella sordida (Zukal) Berron \& Gllaan

Thielavia spedonium Damons

i. terricola (G1lman \& Abbot) Fhaons

DEUTEROMYOTINA

icremonius kiliense crutz

A. restrictum (Van Beyua) V. Cass

icrophialophora fusisnora (Jaksena) Samson

ilternaria alternata (Fr.) Kelsaler.

. humicola OLiemans

Alemaria sp. I

s.1ternaimsp. II

Asporfilius aculcatus Iizuka

א. flavipes (Dain \& Sart.) Thot \& Church

A. flcvus Linic ex Fr. (Strain I)

d. Ilivis Link ex Fr. (Strain II)

^. Nlavus Linic ex Fr. (Strain III)

A. 1umigatus Fres. (Strain I)

A. Iumigatus Fres. (Strain II)

A. funieatus Fres. (Strain III)

A. Eiganteus Vehmer

A. nidulans (Eldam.) Wint (Strain I)

A. nidulons (Eidani.) Wint (Strain II)

A. niger Van Tiegham (Strain I)

A. niger Van Tiegham (Strain II)

A. niveus Blockwitz (Strain I)

A. niveus Rlockuitz (Strain II)

A. ochraceous Wiltelm

A. quercinus (Bainier) Thom \& Church

A. stellatus Curzl

A. terreus Thom

A. ustus (Bainier) Thom \& Church

A. versicolor (Vuilleain) Tirabosch Aspertillus sp.

Cladosporium oxysporum B. \& C.

Coleophoma empetr1 (Rostrup) Petrak

Colletotrichua capsic1 (Syd.) Bulter \& Bisby

Conlothyrium fucklii Sacc.

Curvularia borrerie (Viegas) M.B. Ellis

C. clavata Jain

C. Iunata (Wakker) Boedijn

C. Iunata (Wakker) Boedijn var. aerla (Batista, Liea \& Vasconcelos) M.B. Ellis

C. verruculosa Tandon \& B1lgram1

Cylindrocladium for1danum Sobers \& Seywour

D1plodia state of Otthia spiraeae (Fuckel)Fuckel 
Drecinslera state of Cochliobolus carboins Nelson | Drechslera state of Cochliobolus spicifer Nelson Drechslera state of Trichometasphaeria pedicellata Nelson

Fusarium acuninatum Ell. \& Ev.

F. dimerum Fenz.

F. equiseti (Corda) Sacc.

F, moniliforme Scheld

F. wonillforme var. subflutinans Wollenw. \& Reink.

F. oxysporum Schlecht

F. solani (Mart.) Sacc. (Strain I)

F. solani (Kart.) Sacc. (Strain II)

F. tabacinum (Beyma) y. Gams

Helminthosporium sativun Farmel, King \& Bakke Humicola fusco-atra Traeen (Strain I)

H. fusco-atra Traeen (Strain II)

Macrophomina phaseolina (Tassi) Goid.

Nemnoniella subsimplex (Cda) Deighton

Microascus trigonosporus kmans \& B. Dodge

Nonocilisum constrictum $U$. Gams

Nonodictys fluctuata (Tandon \& Bilgromi)

Nonodictys sp.

Byrotheciul leucotrichum (Fk.) Tulloch

1. verrucaria ( $\mathrm{Al}$, \& Schw.) Ditn, ex $\mathrm{Fr}$.

Paecilonyces lilacinus (Thom) Sanson

Penicilliuis chrysogenum Thom

P. crustosum trom

P. funiculosum Thom

P. implicatum Biourge

P. oxalicum Currie \& Thom

P. spiculisporum Lehman

Fericonia saraswatipurens1s Bleraei

Periconia $\mathrm{sp}$.

Fhialophora cyclaminis Beyma

P. fastigiata (Lagerberg, Lundberg \& Melin) Conant

Fhopa herbarum Vesta.

P. multirostrata (Vathur, Henon \& Thirum.)

Dorenbosch 3: joerema

P. pomorum Thum.

P. putaninu Speg.

Thoma sp.

Fleurophragaium sp.

Polyschema chambalensis Joshi, Chauhan \& Saksena -

Pyrenochaeta abutilonis Nathur, Verma \& Chauhan +

$P$. Indica Vishwanathan

Scolecobasidun constrictus Abbott

S. terreus Abbott

Sphaeronaema allohabadense Chandra \& Tandom

Sporotrichum roseum link

Stachybotrys atra Corda

S. bisbyi (Srinivasan) Barron

Trichodema aureoviride Rifai aggr.

T. harzianum Rifai aggr.

vlocladium chartarum (Preuss) Simons

Zalerion sp.

Sterile colony I

Sterile colony II

Sterile colony III

Sterile colony IV

Sterile colony $\mathbf{v}$

Sterile colony VI

Unidentified colony I

Unidentified colony II

Unidentified colony IrI 


\section{Table 6}

Percentage frequency and abundance (in parentheses below) of some dominant fungt in the non-rhizosphere (NRs), rhizosphere (Rs) and Rhizoplane (Rp) of A. vasica in relation to soil types and seasons

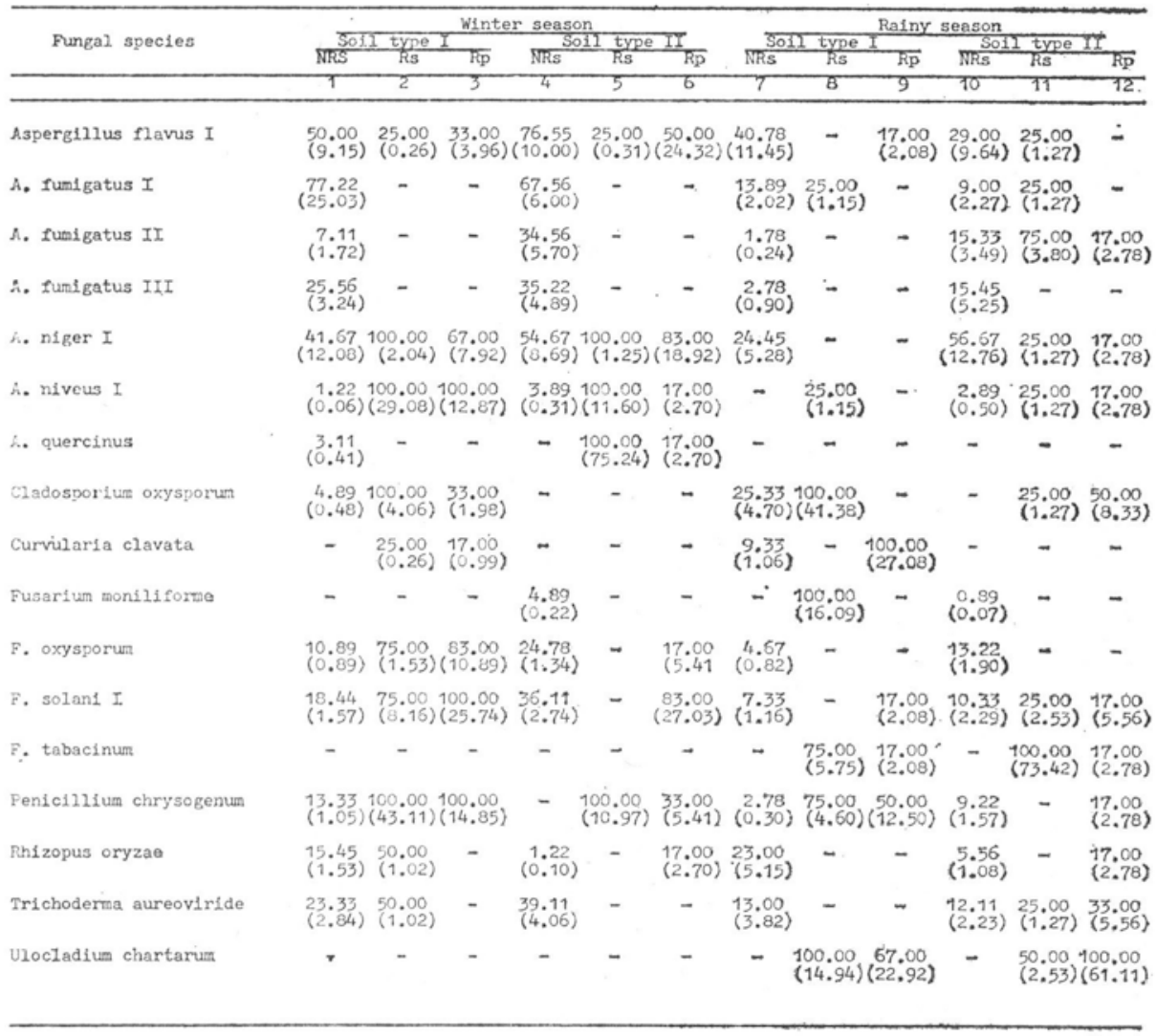




\section{Table 5}

Similarity Quotients (S. Q.) between non-rhizosphere, rhizosphere and rhizoplane mycoflora of Adhatoda vasica in relation to soil types and seasons

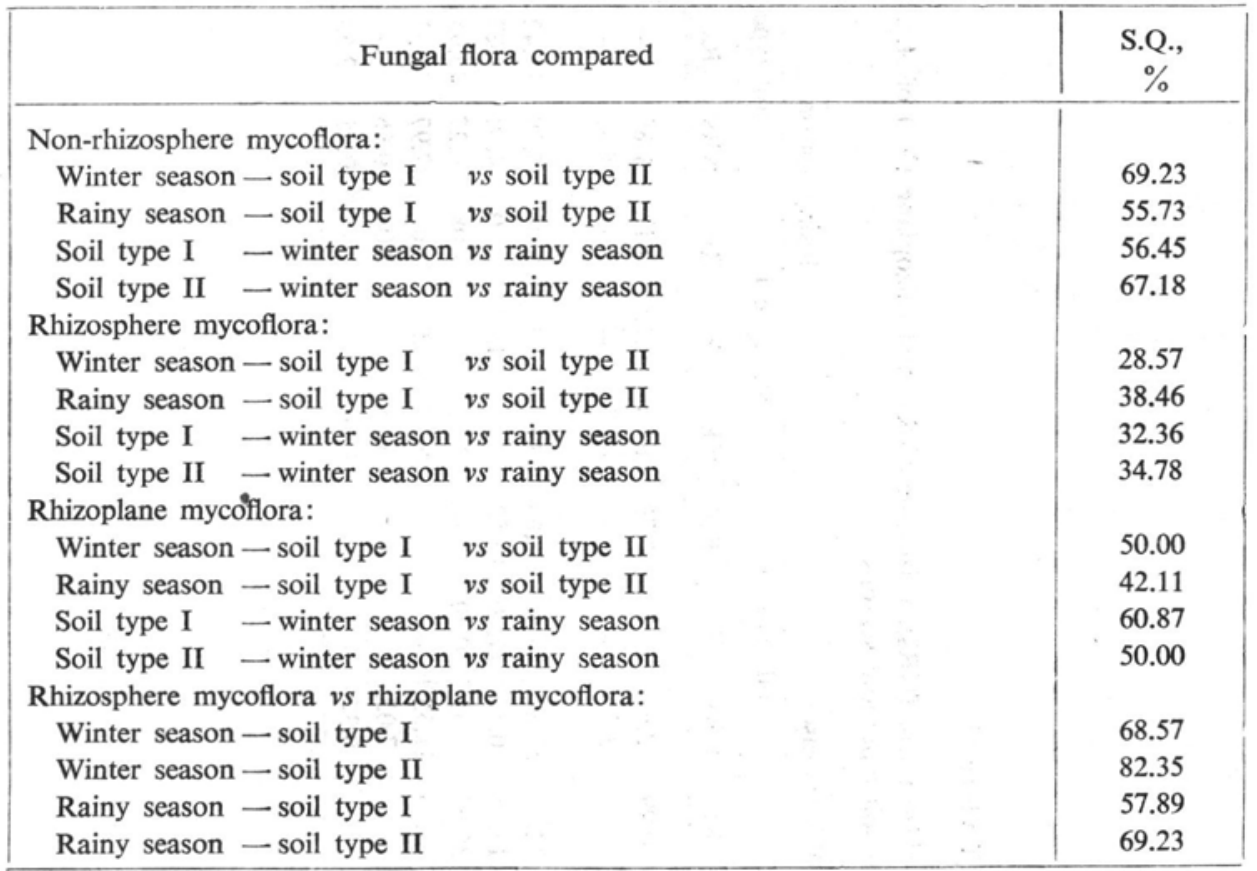

$\mathrm{Ch}$ a $u$ h a n 1981a, b, 1982a). Besides the significant quantitative decline in the non-rhizosphere soil fungal community of both soil types during the rainy season, qualitatively, the extent of similarity between the non-rhizosphere soil mycoflora also decreased considerably during the rainy season (Table 5). The restricted occurrence of certain fungal species in the non-rhizosphere soil of a particular soil type during a particular season (Table 4) indicates the specificity of each non-rhizosphere soil microenvironment which is known to be influenced by the climatic, edaphic and biotic factors ( $\mathrm{J}$ oshi and $\mathrm{Chauhan} 1982 \mathrm{~b}, \mathrm{~J}$ oshi 1983a). However, in general, higher extent of similarities (Table 5) between the fungal flora of the two soil types during the two seasons may be attributed, besides the similar edaphic conditions, to the similar climatic conditions of these two adjoining soil types and the cosmopolitan nature of the fungi.

Due to differences in the non-rhizosphere soil mycoflora of the two soil types, the rhizosphere mycoflora of $A$. vasica growing in the two soil types also differed during both the seasons (Table 3 ) as it is through the non-rhizosphere soil that certain fungi are preferentially stimulated in the vicinity of the roots largely on account of the exudation of metabolically active substances from the roots and sloughed off root cells 
Ta b l c 7

Percentage occurrence of specific fungal groups in the non-rhizosphere (NRs), rhizosphere (Rs) and rhizoplane (Rp) of $A$. vasica in relation to soil types and seasons

\begin{tabular}{|c|c|c|c|c|c|c|c|c|c|c|c|c|}
\hline \multirow{3}{*}{ Fungal groups } & \multicolumn{6}{|c|}{ Winter season } & \multicolumn{6}{|c|}{ Rainy season } \\
\hline & \multicolumn{3}{|c|}{ soil type I } & \multicolumn{3}{|c|}{ soil type II } & \multicolumn{3}{|c|}{ soil type I } & \multicolumn{3}{|c|}{ soil type II } \\
\hline & NRs & Rs & $\mathbf{R p}$ & NRs & Rs & $\mathrm{Rp}$ & NRs & Rs & $\mathbf{R p}$ & NRs & Rs & $\mathbf{R p}$ \\
\hline Zygomycotina & 1.83 & 1.28 & 0.99 & 2.66 & - & 2.70 & 6.16 & 9.20 & 4.17 & 1.89 & - & 2.78 \\
\hline Ascomycotina & 4.03 & - & - & 3.83 & - & - & 4.42 & - & 一 & 4.37 & - & - \\
\hline \multicolumn{13}{|l|}{ Deuteromycotina } \\
\hline Aspergillus & 61.86 & 42.61 & 32.68 & 59.84 & 88.50 & 48.64 & 33.84 & 2.30 & 2.08 & 45.39 & 11.42 & 8.34 \\
\hline Penicillium & 2.85 & 42.11 & 14.85 & 0.44 & 11.20 & 13.52 & 3.96 & 4.60 & 12.50 & 4.80 & 1.27 & 2.78 \\
\hline Fusarium & 2.44 & 3.57 & 36.63 & 4.31 & 0.30 & 35.14 & 3.42 & 21.84 & 2.08 & 4.27 & 45.95 & 5.56 \\
\hline Rest of the hyphomycetes & 22.11 & 9.41 & 14.85 & 21.55 & 一 & - & 43.56 & 62.06 & 77.09 & 37.97 & 38.33 & 24.82 \\
\hline Coelomycetes & 2.61 & 1.02 & - & 7.05 & - & - & 3.85 & - & 2.08 & 0.66 & - & - \\
\hline Sterile colonies & 2.27 & - & - & 0.32 & - & - & 0.79 & 一 & 一 & 0.65 & 2.53 & 5.36 \\
\hline
\end{tabular}

- indicates absence 
(R ovira 1965, 1969). Qualitatively, the rhizosphere mycoflora of A. vasica of both soil types during both the seasons was widely dissimilar (Table 5), whereas, quantitatively, during the rainy season, the rhizosphere fungal population of $A$. vasica of soil type II was significantly higher than that of soil type I (Table 3). The responses of rhizosphere mycoflora to the soil types and seasons were in sharp contrast when compared with the responses of non-rhizosphere soil mycoflora to the soil types and seasons. This suggests the specificity of the rhizosphere mycoflora imparted largely by the root exudates which is directly related to the physiological activities of the plant. Among the environmental conditions affecting the plant growth which consequently affects the root exudation, soil conditions are also known to influence the root surface microflora (L o uw and W ebley 1959). Despite the qualitative and quantitative differences in the root surface mycoflora of different sugarcane varities, Kamal Singh (1974) noted pronunced similarity in their rhizosphere mycoflora and attributed it to the common characteristics of plants and soils. In the present investigation significantly higher rhizosphere fungal community of A. vasica growing in soil type II during the rainy season point towards better growth of plant in soil type II and which, considering the uniform climatic conditions in these two soil types, may consequently be attributed to better edaphic conditions in soil type II. The improved and better soil conditions in the afforested areas of Chambal ravines, which corresponds to the soil type II in the present study, by retaining soil fertility due to afforestation of $P$. juliflora and $D$. sissoo in these areas have already been noted ( $\mathrm{J}$ os hi 1979). Seasonally, A. vasica exhibit luxurient plant growth and flowering during the rainy season and, therefore, the rhizosphere mycoflora increased during the rainy season, although the differences were only significant in soil type II (Table 3). Studies on the rhizosphere mycoflora of Prosopis juliflora and Dalbergia sissoo, both of which undergo flowering at different seasons, also revealed maximum rhizosphere fungal community at their corresponding flowering periods ( $\mathrm{J}$ osh i 1982). Mall (1979) studying the rhizosphere microflora of three varieties of potato noted that the rhizosphere microflora increased with the advancement of the plant growth and was maximum before initiation of tuber formation. It is believed that there is maximum exudation from roots during the flowering period which consequently results in higher rhizosphere fungal community during this period (Srivastava 1973, $\mathrm{S}$ a k s e n a et al. 1982). The wider differences in the species composition of rhizosphere mycoflora of both soil types during both the seasons indicate the differences in their respective microenvironments which consequently result in the occurrence of certain specific fungal species for each. 
During both the seasons, the rhizoplane fungal community of $A$. $v a$ sica growing in soil type I was significantly higher than that of soil type II (Table 3). Seasonally, the rhizoplane fungal community in soil type I decreased significantly during the rainy season. In contrast to the rhizosphere, the rhizoplane mycoflora showed greater similarity (Table 5) with respect to the soil types and seasons. Variations in the qualitative and quantitative parameters of rhizoplane mycoflora led to the specific occurrence of certain fungal species for each soil type and season.

A total of 117 fungal species were isolated during the course of investigation from the non-rhizosphere, rhizosphere and rhizoplane of A. vasica (Table 4). The qualitative and quantitative variations in the non-rhizosphere, rhizosphere and rhizoplane mycoflora were attributed to the wider differences in their respective microenvironments ( $\mathrm{J}$ os h i 1982). In the present investigation maximum fungal community was always noted in the rhizosphere followed by non-rhizosphere soil and least in rhizoplane (Table 3), whereas, qualitatively, maximum number of fungal species were isolated from the non-rhizosphere soil (112 species) followed by rhizosphere (34 species) and lastly rhizoplane (24 species). These findings are in accordance with the studies of most of the workers (Peno and Veselinovic 1973, Srivastava 1973, Joshi 1982, 1983b, Joshi and Chauhan 1982c), although Gangawane and Deshpande (1977) noted higher fungal population in the rhizosphere but failed to find marked qualitative variations, whereas Odunfa and Is o (1979) and Shukla and Dwivedi (1981) recovered maximum number of fungal species from the rhizosphere soil rather than from the non-rhizosphere soil.

In view of the differences in the non-rhizosphere, rhizosphere and rhizoplane microenvironment of $A$. vasica of two soil types during both the seasons, different fungal species dominated in each type of microenvironment (Table 6). Earlier, Shukla and Dwivedi (1981) also noted variations in the percentage occurrence of individual fungal species in the rhizosphere and rhizoplane of primary, secondary and tertiary roots of Trifolium alexandrinum at early, pre-flowering, flowering and fruiting stages. Studies on the rhizosphere mycoflora of certain trees (J o sh i 1982) and crop plants (J oshi and Chauhan 1982c, Joshi $1983 \mathrm{~b})$ have also revealed the same results.

Studies on the rhizosphere mycoflora of different plants revealed that different fungal groups dominate the rhizosphere and rhizoplane at various stages of development of plants. Odunfa and Oso (1979) studying the rhizosphere mycoflora of cowpea noted that with the increasing age some of the early colonizers, viz. Rhizopus spp. and Pythium spp. were replaced by Curvularia spp., certain ascomycetous forms and some drak sterile mycelia. In the present investigation in general, asco- 
mycetous and coelomycetous fungi were mostly isolated from the non-rhizosphere soil (Table 7), whereas they showed poor growth in rhizosphere and rhizoplane. Mishra (1979) studying the fungal flora of certain crop plants also did not observe appreciable number of ascomycetous forms on roots. Some workers have shown Aspergillus to be a typical rhizosphere inhabitant (B a rtoli et al. 1978, M is h r a 1979). Studies on the rhizosphere mycoflora of certain trees (J o s hi 1982), however, revealed the dominance of Aspergillus in the rhizosphere of Prosopis juliflora and Dalbergia sissoo only during the winter season but not during the rainy season. In the present study, in general, Aspergillus spp. were most abundant in the non-rhizosphere soil, followed by rhizosphere and lastly in rhizoplane. (Table 7). Odunfa and Os o (1979) have also noted the abundance of Aspergillus spp. in the non-rhizosphere soil of cowpea in Nigeria. The dominance of Aspergillus spp. in the tropical and subtropical soils has already been reported (D o m s h and G a m s 1972) and they have already been found to be abundant in some other soil types of Chambal ravines ( $\mathrm{J}$ os hi and $\mathrm{Chauhan} \mathrm{1981a,}$ 1982a). Besides Aspergillus, poor growth of Zygomycotina which are represented in the present study by only 3 genera (Table 4) indicate

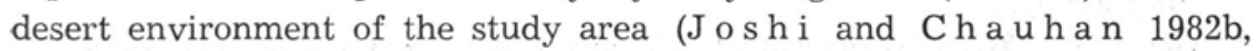
J os h'i 1983a). B o oth (1971) has found Fusarium spp. to be important rhizoplane fungi in many plants. Srivastava (1973), Mishra (1978), Joshi (1982) and Joshi and Chauhan (1982c) have also found Fusarium to be dominant rhizoplane fungi. Thom as and $\mathrm{Par}-$ kins on (1967) opined that the infrequent isolation of Fusarium spp. from soil dilution plates, used for estimating rhizosphere mycoflora, is due to the fact that they are restricted in the soil to the fragments of the organic matter where they may be present as chlamydospores or as mycelia and that the dilution plate technique is unsuitable for isolating fungi associated with organic fragments in the soil. Odunfa and O s o (1979), therefore, noted considerably low frequency of Fusarium spp. in rhizosphere than in rhizoplane. In the present investigation, however, during the winter season Fusarium spp. dominated the rhizoplane of both soil types, whereas during the rainy season, they dominated the rhizosphere of both soil types (Table 7). Parkinson and Pearson $(1967 \mathrm{a}, \mathrm{b})$ studied the occurrence and competitive ability of sterile dark fungi on barley root surface and found that sterile dark fungi were rapid colonizers on young roots and persisted there with increasing age. M i s$\mathrm{h} \mathrm{r}$ a (1978) recorded occurrence of sterile dark mycelia on rhizoplane of certain fibre-yielding plants from seedling to fruiting age. M a 11 (1979) also noted abundance of sterile forms in the rhizoplane of three varieties of potato. In the present study, however, it was only during the rainy season that from the rhizosphere and rhizoplane of $A$. vasica growing in soil type II certain sterile mycelia were isolated. 
Acknowledgments

The author is grateful to Dr R. K. S. Chauhan and Prof. S. B. Sakse$\mathrm{n}$ a, School of Studies in Botany, Jiwaji University, Gwalior for valuable suggestions; Dr A. Johnston, Director, CMI, England for helping in the identification of fungal species; and to the Head, School of Studies in Botany, Jiwaji University, Gwalior for providing laboratory facilities.

\section{REFERENCES}

Bartoli A., Maggi O., Albonetti S. G., P'uppi G., Rambelli A., 1978. Research on the rhizosphere of Loudetia simplex C. E. Hubbard, typical grass of Ivory Coast: Final Report. G. Bot. Ital. 112: 75-96.

B o o th C., 1971. The Genus Fusarium. CMI, Kew, England.

Domsch K. H., Gams W., 1972. Fungi in Agricultural Soil. T. and A. Constable Ltd., Edinburgh.

Gangawane L. V., Deshpande K. B., 1977. Seasonal variation in rhizosphere mycoflora of groundnut. J. Indian Bot. Soc. 56: 289-295.

Harle y J. L., W a id J. S., 1955. A method of studying active mycelia on living root and on other surfaces in the soil. Trans. Br. Mycol. Soc. 38: 104-118.

Jackson M. L., 1958. Soil Chemical Analysis. Printice Hall, Englewood Cliffs, New Jersey.

Joshi I. J., 1979. Development of soil microflora in relation to plant succession on certain areas of Chambal ravines. Ph. D. Thesis, Jiwaji University, Gwalior, India.

J o s hi I. J., 1982. Studies on rhizosphere mycoflora of certain trees. Acta Soc. Bot. Pol. 51: 493-501.

Joshi I. J., 1983a. Investigations into the soil mycoecology of Chambal ravines of India. II. Fungal communities in Brassica campestris crop fields and their seasonal succession Plant and Soil 67: (In Press).

Joshi I. J., 1983b. Studies on rhizosphere mycoflora of Gajanus cajan (L.) Millsp. during pre-harvest and post-harvest periods. Microbiol. Espanola (In Press).

Joshi I. J., Chauhan R. K. S., 1981a. Soil fungal ecology of cultivated areas of Chambal ravines. Proc. Indian Natn. Sci. Acad. B47: 248-254.

Joshi I. J., Chauhan R. K. S., 1981b. Ecological studies no fungal flora of Cajanus cajan (Linn.) Millsp. Proc. Nat. Acad. Sci. India 51B: 233-239.

Joshi I. J., Chauhan R. K. S., 1982a. Distribution of soil microfungi in various soil types of Chambal ravines. Proc. Indian Natn. Sci. Acad. B48: 513-521.

Joshi I. J., Chauhan R. K. S., 1982b. Investigations into the soil mycoecology of Chambal ravines of India. I. Fungal communities and seasonal succession. Plant and Soil 66: 329-338.

Joshi I. J., Chauhan R. K. S., 1982c. Studies on mycoflora associated with soil, rhizosphere and rhizoplane of wheat. Geobios New Rep. 1: 161-163.

$\mathrm{Ka}$ a l, Sing h N. P., 1974. On microfungi from root region of ten sugarcane varieties. Indian Phytopath. 37: 347-354.

Kanazawa S., 1979. Studies on plant debris in rice paddy soils. I. Morphological observations and numbers of microbes in fractionated plough layer of paddy soils. Soil Sci. Plant Nutr. 25: 59-70.

Karimbaeva L. Y., Sizova T. P., 1976. Fungal flora of the rhizosphere of some woody species. Vestn. Mosk. Univ. Ser. VI Biol. Pochvoved. 31: 24-29. 
Katznelson H., Rouatt J. W., 1957. Manometric studies with rhizosphere and non-rhizosphere soil. Can. J. Microbiol. 3: 673-678.

K i e m R., W ebster R. K., W ick C. M., 1975. Quantitatie effects of incorporating rice residue on populations of soil microflora. Mycologia 67: 280-291.

Louw H. A., Webley D. M., 1959. The bacteriology of the root region of the oat plant grown under controlled pot culture conditions. J. Appl. Bact. 22: 216-226.

M a 11 S., 1979. Rhizosphere and rhizoplane microflora of three potato varieties. Indian Phytopath. 32: 51-54.

Martin J. P., 1950. Use of acid, rose bengal and streptomycin in the plate method for estimating soil fungi. Soil Sci. 69: 215-232.

Mishra K. B., 1978. Rhizoplane mycoflora of fibre-yielding plants. Indian Phytopath. 31: 21-23.

Mishra R. R., 1979. Root decomposition. Proc. Indian Natn. Sci. Acad. B45: 648-659.

Mishra R. R., Kanaujia R. S., 1973. Investigations into rhizosphere mycoflora XII. Seasonal variation in the mycoflora of certain gymnosperms. Sydowia, Ann. Mycol. Ser. II27: 302-311.

Odunfa V. S. A., Oso B. A., 1979. Fungal populations in the rhizosphere and rhizoplane of cowpea. Trans. Br. Mycol. Soc. 73: 21-26.

Papavizas G. C., Davey C. B., 1959. Evaluation of various media and antimicrobial agents for isolation of soil fungi. Soil Sci. 88: 112-117.

Parkinson D., Pearson R., 1967a. Studies on fungi in the root region VI. The occurrence of sterile dark fungi on root surface. Plant and Soil 27: 113-119.

Parkinson D., Pears on R., 1967b. Studies on fungi in the root region VII. Competitive ability of sterile dark fungi. Plant and Soil 27: 120-130.

Peno M., Veselinovic N., 1973. Dinamika populacija glijivicnih organizama a rizosferi Pinus nigra Arn., S. Posebnium Osvrtom no patogene Fusarium Vrste, Mikrobiologija (Belgr.) 10: 289-292.

Pidoplichko N. M., Moskovets V. S.,' Z'h danova N. M., 1965. Influence of some fungi from the maize rhizosphere on the growth of its seedlings. In: Plant Microbes Relationships. Mancura I., and Manenra V. (eds.). Chechoslovak Acad. Sci. Publ. House, Prague. pp. 220-227.

Pi per C. S., 1944. Soil and Plant Analysis. University of Adelaide, S. Australia.

Rovira A. D., 1965. Plant root exudates and their influence upon soil microorganisms, In: Ecology of soil borne Plant Pathogens - Prelude to Biological Control. Baker, K. F., and Snyder W. C. (eds.). Berkeley Univ. California Press. pp. 170-186.

Rovira A. D., 1969. Plant root exudates. Bot. Rev. 35: 17-34.

Saksena S. B., 1955. Ecological factors governing distribution of soil microfungi in some forest soils of Sagar. J. Indian Bot. Soc. 34: 262-298.

Saksena S. B., Mehrotra R. S., Aneja K. R., 1982. Rhizosphere and biological control. Cur. Trends Life Sci. 9: 169-188.

Shukla S. N., Dwivedi R. S., 1981. Qualitative and quantitative studies on rhizosphere and rhizoplane microflora of Trifolium alexandrinum Linn. Proc. Indian Natn. Sci. Acad. B47: 899-906.

Sorensen T., 1948. A method of establishing groups of equal amplitude in plant sociology based on similarity of species content. Dansk. Vidensk. Biol. Skr. 5: 1-34.

Srivastava V. B., 1973. Investigations into rhizosphere microflora. IV. Fungal association in different root regions of some rainy season crops. Acta Soc. Bot. Pol. 42: 409-422. 
S tover R. H., W a ite B. H., 1953. An improved method for isolating Fusarium spp. from plant tissue. Phytopathology 43: 700-701.

Subba Rao N. S., Bidwell R. G., Bailey D. L.,' 1961. Efect of fungi on the uptake and metabolism of nutrients by tomato-plants. Can. J. Bot. 39: 1759-1764.

Timonin M. I., 1940. The interactions of higher plants and soil microorganisms. I. Microbial population of rhizosphere of seedlings of certain cultivated plants. Can. J. Res. 18: 307-317.

Thomas A., Parkinson D., 1967. The initiation of rhizosphere mycoflora of dwarf bean plants. Can. J. Microbiol. 13: 439-446.

W a r c p J. H., 1950. The soil plate method for isolation of fungi from soil. Nature 166: 117.

\title{
Wplyw warunków glebowych $i$ kwitnienia na mykoflorę gleby strefy korzeniowej Adhatoda vasica Nees
}

\author{
Streszczenie
}

Badano mykoflorę Adhatoda vasica Nees, rosnącą na dwóch różnych typach gleby, ze strefy poza korzeniowej (poza-ryzosfery), w glebie strefy korzeniowej (ryzosferze) i z powierzchni korzeni (ryzoplany). Badania wykonywano w zimie i w porze deszczowej. Wyizolowano ogółem 117 gatunków. W zimie mykoflora z poza-ryzosfery z gleby II typu, zawierającej więcej węgla, była wyraźnie bogatsza w gatunki niż w glebie I typu. Mykoflora poza-ryzosferą w porze deszczowej znacznie zmniejszyła się, co było związane z wyraźnie większą wilgotnością gleby i z jej większą zdolnością zatrzymywania wody. Zbiorowiska grzybów z ryzosfery A. vasica podczas pory deszczowej różniły się w zależności od typu gleby. Maksimum zbiorowisk grzybów zanotowano w ryzosferze w porze deszczowej, kiedy roślina rosła najbujniej i kwitła. Mykoflora w ryzosferze A. vasica wyraźnie różniła się jakościowo w zależności od typu gleby i sezonu. Mykoflora ryzoplany również wykazywała różnice zależne od typu gleby i sezonu ale znacznie mniejsze. Najwięcej zbiorwoisk grzybów zanotowano w ryzosferze, następnie poza-ryzosferą, a najmniej w ryzoplanie, podczas gdy największą liczbę gatunków grzybów w glebie poza-ryzosferą, następnie w ryzosferze i najmniejszą w ryzoplanie. Odmienne gatunki grzybów dominowały w glebie poza-ryzosferą, w ryzosferze i ryzoplanie A. vasica na obu typach gleby i w obu sezonach. Aspergillus spp. występował najobficiej w glebie poza-ryzosferą. W obu typach gleby Fusarium spp. dominowało w ryzoplanie w zimie i w ryzosferze w porze deszczowej. 